\title{
EVALUASI GEOMETRIK, KINERJA DAN PERKERASAN LENTUR JALAN RAYA GUMITIR KABUPATEN JEMBER
}

(Study kasus Rest Area Gumitir, Kecamatan Silo, Kabupaten Jember)

\author{
Abdi Zulkarnain ${ }^{1}$, Irawati ${ }^{2}$, Taufan Abadi $^{3}$. \\ Program Studi Teknik Sipil, Fakultas Teknik, Universitas Muhammadiyah Jember ${ }^{1}$ \\ Jl. Karimata 49, Jember 68121, Indonesia \\ Email : abdizulkarnain15@gmail.com \\ Program Studi Teknik Sipil, Fakultas Teknik, Universitas Muhammadiyah Jember ${ }^{2}$ \\ Jl. Karimata 49, Jember 68121, Indonesia \\ Program Studi Teknik Sipil, Fakultas Teknik, Universitas Muhammadiyah Jember ${ }^{3}$ \\ Jl. Karimata 49, Jember 68121, Indonesia
}

\begin{abstract}
Gumitir highway is a class I highway as a cross road between regencies and cities (Jember Banyuwangi). The condition of this highway field with a width of 7 meters and winding and there are slopes. This highway is passed by heavy vehicles which can cause overloading (tonnage) loading, damage to the road body. Under these conditions a geometric evaluation (of the length of the arch) and calculation of the thickness of the flexible pavement on the Gumitir highway in Jember Regency .. This study aims to (1) analyze the performance of the Gumitir highway, (2) analyze the geometric of the Gumitir highway STA $229+664$ - STA + 019, (3) analyzing the flexible pavement conditions with the 2013 UR 20-year bina marga method, (4) analyzing the inventory of the Gumitir highway. The research was conducted using the Full Circle method to calculate the geometric conditions of the Gumitir highway and 2013 Bina Marga UR 20 method for calculating the thickness of the pavement thickness of the Gumitir highway. The results of the 2013 Bina marga pavement thickness calculation results obtained for a flexible pavement thickness of $44 \mathrm{~cm}$, a $3 \mathrm{~cm}$ HRS WC, a $3.5 \mathrm{~cm}$ HRS Base, a $25 \mathrm{~cm}$ LPA Class A and LPA Class B $12.5 \mathrm{~cm}$. The results of planning the addition of warning signs point obtained 8 electric poles, 10 street lighting lamps, 8 traffic signs (addition 8 points) and longitudinal road markings in the form of solid lines
\end{abstract}

Keyword: Highway, Jember, Flexible pavement, geometric evaluation

\section{PENDAHULUAN}

Kondisi medan jalan raya Baluran yaitu berliku dan terdapat kelandaian (vertikal). Dengan lebar jalan $=7$ meter, jalan raya ini banyak dilewati kendaraan berat. Adapun contoh kendaraan berat seperti kendaraan pribadi, Bus, Truk 2 as, Truk 3 as, Truk gandengan dan Truk semi/trailer. Volume kendaraan yang padat ini mengakibatkan terjadinya pembebanan pada jalan tersebut. Dengan pembebanan (tonase) yang overloading ini mengakibatkan seringnya kerusakan pada badan jalan.

Disamping itu, dengan tikungan-tikungan yang tajam (kurve horisontal) dan kelandaian tanjakan dan turunan (kurve vertikal) dapat memberi jarak pandang pengemudi yang kurang baik.

\section{Rumusan Masalah}

Rumusan permasalah dalam penelitian dan pembahasan Tugas akhir ini, adalah:

1. Bagaimana kinerja jalan raya Gumitir STA 229+644 - STA 230+019 Kabupaten Jember saat ini?.

2. Bagaimana kondisi geometrik jalan raya Gumitir STA 229+644 - STA 230+019 Kabupaten Jember?.

3. Bagaimana mengevaluasi kondisi perkerasan lentur dengan metode bina marga 2013 UR 20 tahun jalan raya Gumitir Kabupaten Jember?.

4. Bagiamana kelengapan inventaris jalan pada jalan raya Gumitir STA 229+644 STA 230+019 Kabupaten Jember?

\section{Tujuanpenelitian}

penelitian ini bertujuan untuk : 
1. Menganalisa kinerja jalan pada jalan raya Gumitir STA 229+644 - STA 230+019 Kabupaten Jember.

2. Menganalisa geometrik jalan raya Gumitir STA 229+644 - STA 230+019 Kabupaten Jember dengan metode lingkaran sederhana (Full circle) saat ini.

3. Menganalisa evaluasi perencanaan tebal perkerasan lentur dengan metode Bina Marga 2013 UR 20 tahun pada jalan raya Gumitir Kabupaten Jember.

4. Menganalisa kelengkapan inventaris jalan pada jalan raya Gumitir STA 229+644 STA 230+019 Kabupaten Jember saat ini.

\section{Batasan Masalah}

batasan masalah dalam penelitian ini sebagai berikut:

1. Penelitian ini dilaksanakan di jalan raya Gumitir STA 229+644 - STA 230+019 Kabupaten Jember.

2. Mengevaluasi kinerja jalan raya Gumitir STA 229+644 - STA 230+019 Kabupaten Jember.

3. Mengevaluasi geometric sebanyak 4 tikungan di jalan raya Gumitir STA 229+644 - STA 230+019 Kabupaten Jember.

4. Mengevaluasi perencanaan tebal perkerasan lentur dengan metode Bina Marga 2013 UR 20 tahun pada jalan raya Gumitir STA 229+644 - STA 230+019 Kabupaten Jember.

5. Mengevaluasi kelengkapan inventaris jalan pada jalan raya Gumitir STA 229+644 - STA 230+019 Kabupaten Jember.

6. Pengambilan data geometrik dan pengamatan volume kendaraan :

a. Data setting dan stationing atau pengidentifikasian lokasi penelitian.

b. Data beda tinggi dan jarak/panjang $(\mathrm{H})$.

c. Data sudut Azimuth $(\psi)$ dan sudut horisontal $(\beta)$.

d. Data situasi lokasi penelitian.

e. Data volume kendaraan didapat dari pengamatan langsung (primer) atau dari Dinas Pekerjaan Umum (sekunder), dan

f. Tidak menghitung anggaran biaya (RAB).

\section{Manfaat Penelitian}

Manfaat penelitian ini adalah sebagai berikut :

1. Dari hasil penelitian ini diharapkan dapat memberikan sumbangan pemikiran dan dapat digunakan sebagai bahan pertimbangan bagi Pemerintah terutama Dinas PU Bina Marga dalam pelaksanaan atau pengambilan kebijakan nantinya.

2. Hasil penelitian ini diharapkan dapat dijadikan bahan informasi bagi pihak yang berkepentingan.

3. Menambah wawasan secara teknis dalam survey dan geometrik jalan raya dan perencanaan tebal perkerasan lenturnya.

\section{Lokasi Penelitian}

Lokasi penelitian Tugas Akhir ini dilaksanakan di Jalan Raya Baluran KM 248 250 Kabupaten Situbondo, atau 248 sampai 250 kilometer arah timur Surabaya. Lokasi penelitian ini merupakan jalan raya dengan kelas I yang menghubungkan Kabupaten Situbondo dan Banyuwangi, serta merupakan jalan penghubung antar provinsi (Jawa-Bali).

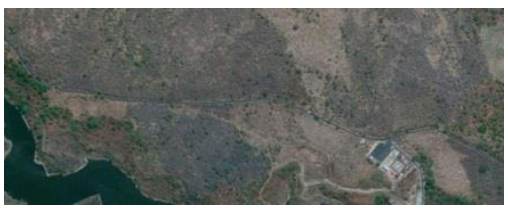

Gambar 1. Lokasi Penelitian Tugas Akhir

\section{TAHAPAN PENELITIAN}

Berikut ini adalah diagram alur untuk tahapan penelitian :

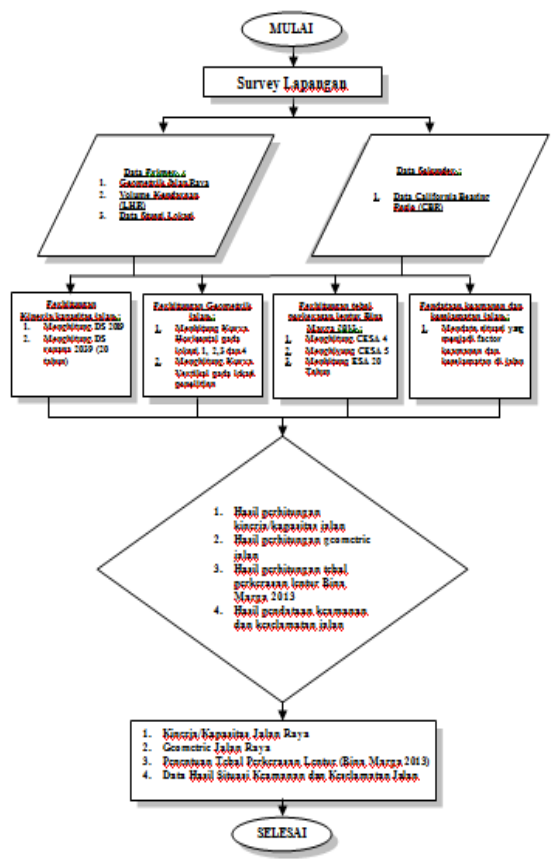

Gambar 2. Diagram Alir

HASIL DAN PEMBAHASAN 
Derajat Kejenuhan (Ds) Perhitungan Ds 2019

Hasil perhitungan DS 2019 disajikan dalam tabel 1 berikut ini.

Tabel 1. Hasil perhitungan DS 2019

\begin{tabular}{|c|c|c|c|c|c|c|c|c|}
\hline \multirow[t]{2}{*}{ Arah } & \multirow{2}{*}{$\begin{array}{l}\text { Pukul } \\
\\
\text { (WIB) }\end{array}$} & \multirow[t]{2}{*}{$\begin{array}{r}\text { Sepeda } \\
\text { motor, } \\
\text { roda 3, } \\
\text { Vespa }\end{array}$} & \multirow[t]{2}{*}{\begin{tabular}{|c|} 
Mobil \\
pribadi, \\
mobil \\
hantaran, \\
pickup, \\
mobil \\
box. \\
LV \\
\end{tabular}} & \multirow[t]{2}{*}{$\begin{array}{c}\begin{array}{c}\text { Bus, Truk } 2 \\
\text { as, Truk } 3 \\
\text { as, Truk } \\
\text { Gandengan, } \\
\text { semi/trailer }\end{array} \\
\text { HV } \\
\end{array}$} & \multicolumn{3}{|c|}{ Q SMP } & \multirow[t]{2}{*}{$\begin{array}{l}\text { Total } \\
\text { SNIP }\end{array}$} \\
\hline & & & & & MC & LV & $\mathrm{HV}$ & \\
\hline $\begin{array}{c}\text { Banyuwangi } \\
\text { - Jember }\end{array}$ & $\begin{array}{l}07.00- \\
08.00\end{array}$ & 269 & 99 & 103 & 67.25 & 99 & 123.6 & 289.85 \\
\hline $\begin{array}{l}\text { Jember- } \\
\text { Banyuwang }\end{array}$ & \begin{tabular}{|l|l}
$07.00-$ \\
08.00
\end{tabular} & 301 & 99 & 92 & 75.25 & 99 & 110.4 & 284.65 \\
\hline ta & & 570 & 198 & 195 & 142.5 & 198 & 234 & 574.5 \\
\hline
\end{tabular}

Untuk C smp = 3100 smp/jam dan Qsmp = $564,3 \mathrm{smp} / \mathrm{jam}$, sehingga didapat DS, sebagai berikut :

DS $=Q / C=574,5 / 3000$

$$
=0,185(\mathrm{~A})
$$

Perhitungan Ds 2039

Hasil perhitungan DS 2039 disajikan dalam tabel 2 berikut ini.

Tabel 2. Hasil perhitungan DS 2019

\begin{tabular}{|c|c|c|c|c|}
\hline No & Jenis Kendaraan & $\begin{array}{l}\text { LHR } \\
2039\end{array}$ & $\begin{array}{c}\text { EMP } \\
\text { MKJI } \\
1997\end{array}$ & Q SMP \\
\hline 1 & MC & 1512.380 & 0.250 & 378.095 \\
\hline 2 & LV & 525.353 & 1.000 & 525.353 \\
\hline 3 & $\mathrm{HV}$ & 517.393 & 1.200 & 620.872 \\
\hline \multicolumn{2}{|r|}{ Total } & & & 1524.320 \\
\hline
\end{tabular}

C smp $=3100 \mathrm{smp} / \mathrm{jam}$ dan Qsmp $=1497,256$ smp/jam, sehingga didapat DS, sebagai berikut :

DS $\quad=Q / C=1524,320 / 3000$

$$
=0,492(C)
$$

Dari perhitungan diatas didapatkan kategori tingkat pelayanan seperti pada tabel 3 berikut ini.

\begin{tabular}{|c|c|c|}
\hline $\begin{array}{l}\text { Tingkat } \\
\text { pelayanan }\end{array}$ & Kriteria & Nilai \\
\hline $\mathrm{A}$ & $\begin{array}{l}\text { Kondisi arus dengan kecepatan tinggi dan volume lalu- } \\
\text { lintas rendah.Pengemudi dapat memilih kecepatan yang } \\
\text { diinginkannya tanpa hambatan }\end{array}$ & $0.00-0.19$ \\
\hline B & $\begin{array}{l}\text { Dalam zone harus stabil.Pengemudi memiliki kebebasan } \\
\text { yang cukup untuk memilih kecepatannya }\end{array}$ & $0.20-0.44$ \\
\hline C & $\begin{array}{l}\text { Dalam zone arus stabil pengemudi dibatasi dalam } \\
\text { memilih kecepatannya }\end{array}$ & $0.45-0.74$ \\
\hline D & $\begin{array}{l}\text { Mendekati arus tidak stabil dimana hampir seluruh } \\
\text { pengemudi akan dibatasi volume pelayanan berkaitan } \\
\text { dengan kapasitas yang dapat ditolerir (diterima) }\end{array}$ & $0.75-0.84$ \\
\hline E & $\begin{array}{l}\text { Volume arus lalu-lintas mendekati atau berada pada } \\
\text { kapasitasnya.Arus adalah tidak stabil dengan kondisi } \\
\text { yang sering berhenti }\end{array}$ & $0.85-1.0$ \\
\hline F & $\begin{array}{l}\text { Arus yang sering dipaksakan atau macet pada kecepatan- } \\
\text { kecepatan yang rendah.Antrian yang panjang dan terjadi } \\
\text { hambatan-hambatan yang besar }\end{array}$ & $\begin{array}{l}\text { Lebih besar } \\
\text { dari } 1.0\end{array}$ \\
\hline
\end{tabular}

Tabel 3. Kriteria \& Tingkat Pelayanan Jalan

\section{Geometrik Jalan}

\section{Data Jarak Dan Hitungan}

Pengukuran jarak (meter) penelitian Tugas akhir ini dilakukan secara langsung dilapangan menggunakan Digital Measuring Wheel. hasil pengukuran disajikan pada tabel 4 sampai dengan tabel 7 berikut ini:

Tabel 4.Hasil Pengukuran 1

\begin{tabular}{cc}
\hline Titik & $\begin{array}{c}\text { Panjang/Jarak } \\
\text { (Meter) }\end{array}$ \\
\hline $1-2$ & $\mathbf{2 3 , 3 5}$ \\
$2-3$ & $\mathbf{2 8 , 6 5}$ \\
Jumlah & 52
\end{tabular}

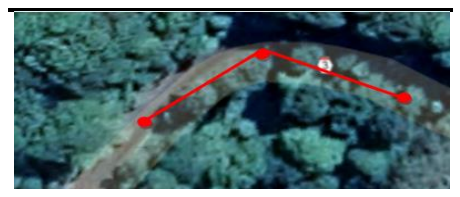

Gambar 2. Lokasi penelitian I

Tabel 4.Hasil Pengukuran 2

Titik Panjang/Jarak (Meter)

\begin{tabular}{cc|}
\hline $1-2$ & 33 \\
\hline $2-3$ & 30 \\
\hline Jumlah & 63 \\
\hline
\end{tabular}

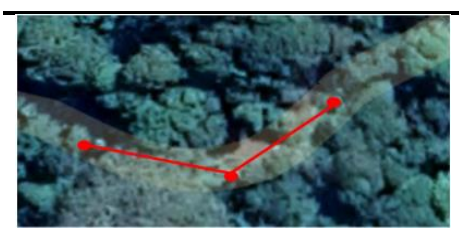

Gambar 3.Lokasi Penelitian II

$\underline{\text { Tabel 4.Hasil Pengukuran } 3}$

\begin{tabular}{cc}
\hline Titik & $\begin{array}{c}\text { Panjang/Jarak } \\
\text { (Meter) }\end{array}$ \\
\hline $1-2$ & 25,43 \\
$2-3$ & $\mathbf{2 8 , 5 7}$ \\
Jumlah & 54
\end{tabular}

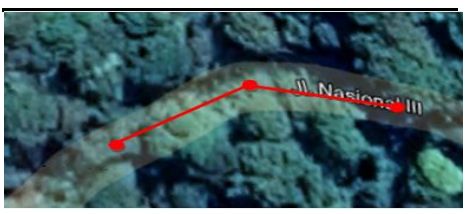

Gambar 4. Lokasi Penelitian III

$\underline{\text { Tabel 4.Hasil Pengukuran } 4}$

\begin{tabular}{cc}
\hline Titik & $\begin{array}{c}\text { Panjang/Jarak } \\
\text { (Meter) }\end{array}$ \\
\hline $1-2$ & 26 \\
$2-3$ & 23 \\
Jumlah & 49 \\
\hline
\end{tabular}




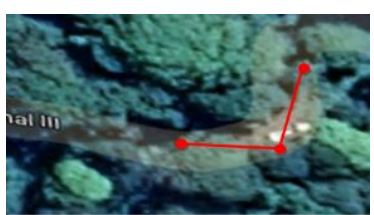

Gambar 5. Lokasi Penelitian IV

\section{Data Beda Tinggi}

Pada pengukuran beda tinggi diambil dengan alat Total Station. Adapun pengukurannya terdapat 2 pengukuran, yaitu long section dan cross section.

Data Pengkuran Long Section dan Cross Section Lokasi Penelitian I :

\begin{tabular}{|c|c|c|c|c|}
\hline $\begin{array}{c}\text { Nomor } \\
\text { Titik }\end{array}$ & $\mathbf{X}$ & $\mathbf{Y}$ & $\mathbf{Z}$ & Notasi \\
\hline 11 & 76.677 & 79.99 & 11.028 & B2 \\
\hline 17 & 91.056 & 99.435 & 9.216 & B3 \\
\hline 23 & 86.729 & 125.43 & 7.707 & B4 \\
\multicolumn{5}{c}{ LONG SECTION } \\
\hline
\end{tabular}

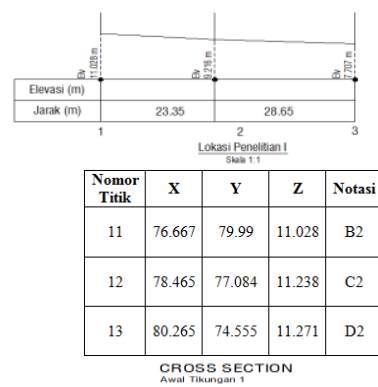

$\mathrm{U}$
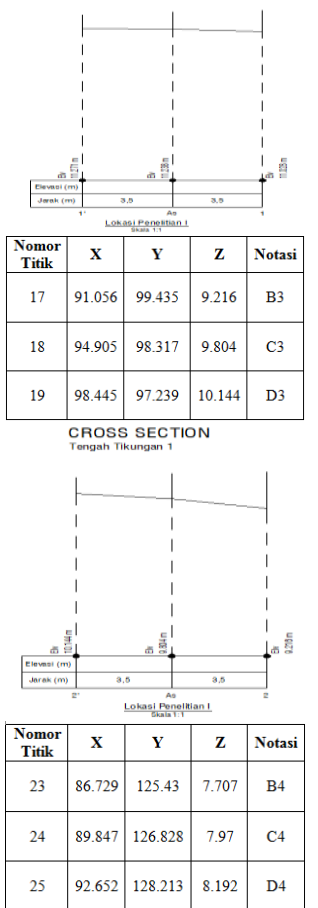

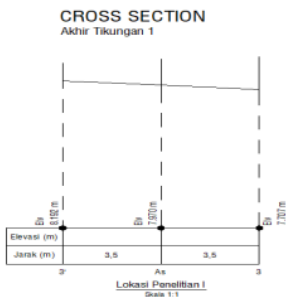

Data Pengkuran Long Section dan Cross Section Lokasi Penelitian II:
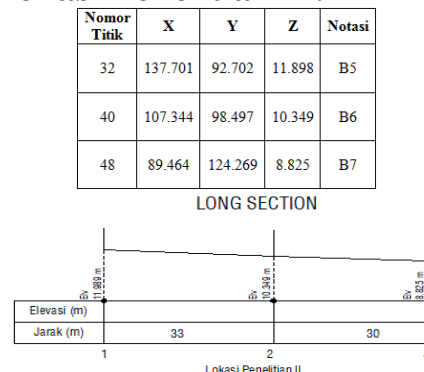

Lokasi Penelitian

\begin{tabular}{|c|c|c|c|c|}
\hline $\begin{array}{c}\text { Nomor } \\
\text { Titik }\end{array}$ & $\mathbf{X}$ & $\mathbf{y}$ & $\mathbf{Z}$ & Notasi \\
\hline 32 & 137.701 & 92.702 & 11.898 & B5 \\
\hline 34 & 137.68 & 96.094 & 11.835 & C5 \\
\hline 35 & 137.6 & 99.948 & 11.53 & D5 \\
\hline \multicolumn{5}{|c}{ CROSS SECTION } \\
\hline
\end{tabular}
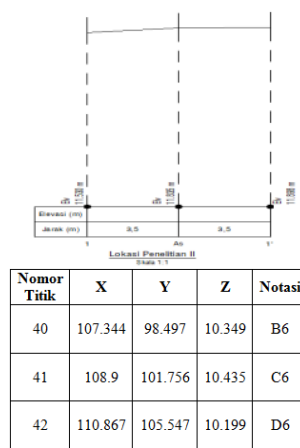

CROSS SECTION
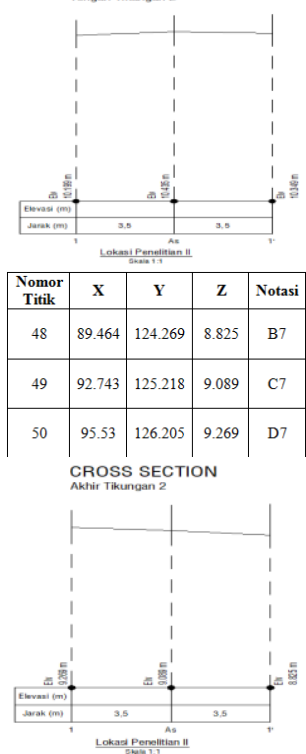

Data Pengkuran Long Section dan Cross Section Lokasi Penelitian III: 


$$
\begin{array}{|c|c|c|c|c|}
\hline \begin{array}{c}
\text { Nomor } \\
\text { Titik }
\end{array} & \mathbf{X} & \mathbf{Y} & \mathbf{Z} & \text { Notasi } \\
\hline 60 & 62.378 & 166.51 & 6.203 & \text { B9 } \\
\hline 68 & 91.611 & 84.509 & 7.521 & \text { B10 } \\
\hline 75 & 74.001 & 64.522 & 5.691 & \text { B11 } \\
\hline \multicolumn{5}{|c}{\text { LONG SECTION }} \\
\hline
\end{array}
$$

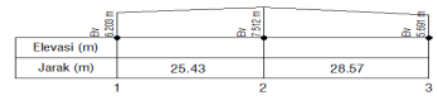

Lokasi Peneritian III

\begin{tabular}{|c|c|c|c|c|}
\hline $\begin{array}{c}\text { Nomor } \\
\text { Titik }\end{array}$ & $\mathbf{X}$ & $\mathbf{Y}$ & $\mathbf{Z}$ & Notasi \\
\hline 60 & 62.378 & 166.51 & 6.203 & B9 \\
\hline 61 & 65.382 & 168.646 & 6.38 & C9 \\
\hline 62 & 67.801 & 170.156 & 6.448 & D9 \\
\multicolumn{5}{|c|}{ CROSS SECTION } \\
\hline
\end{tabular}

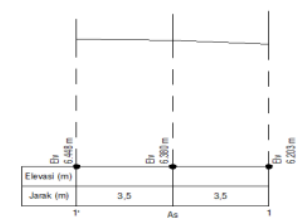

Lokxes Panatitian II
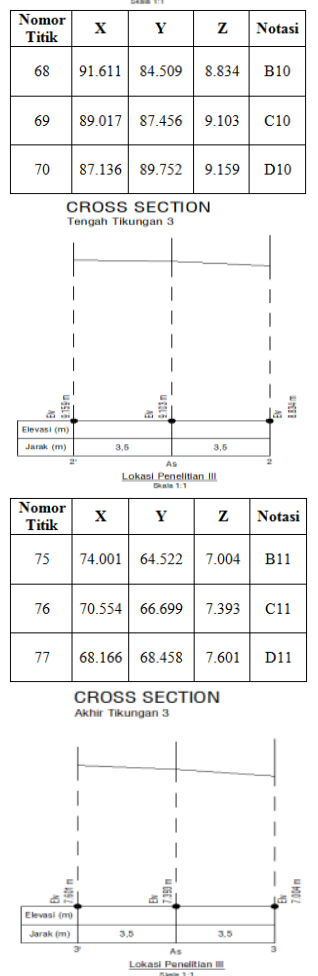

Data Pengkuran Long Section dan Cross Section Lokasi Penelitian IV:

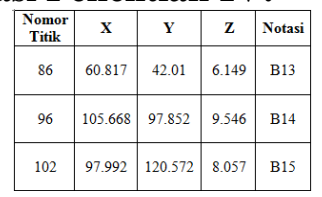

LONG SECTION

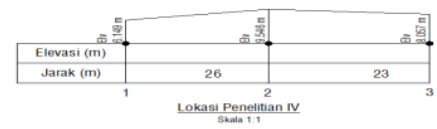

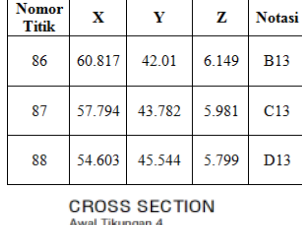
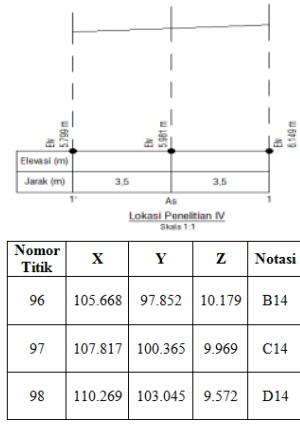
CROSS SECTTION
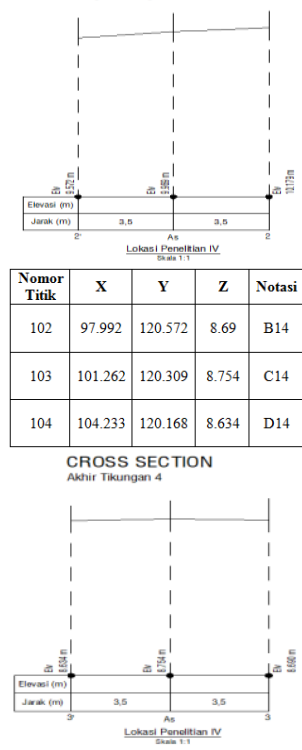

Perhitungan Geometrik

\section{(Curve Horisontal)}

perhitungan kurve vertikal dari ke empat lokasi penelitian sebagai berikut:

$$
\begin{aligned}
\mathrm{LC} & =\pi \mathrm{R} \Delta / 180^{\circ} \ldots \ldots .(3) \\
\mathrm{C} & =2 \mathrm{R} \sin (\Delta / 2) \\
\mathrm{T} & =\mathrm{R} \tan (\Delta / 2) \\
\mathrm{ES} & =\mathrm{T} \tan (\Delta / 4) \ldots \ldots(4)
\end{aligned}
$$

$\mathrm{V}=40 \mathrm{~km} / \mathrm{jam}$ (rencana kecepatan minimum)

$R \quad=V^{2} / 127\left(e_{\text {maks }}+f_{\text {maks }}\right) \ldots \ldots \ldots(5)$

$\mathrm{e}_{\text {maks }}=0,10 \mathrm{~m} / \mathrm{m} ; \quad \mathrm{f}_{\text {maks }}=0,166$

Maka :

$\mathrm{R} \min =40^{2} / 127(0,10+0,166)$

$\mathrm{R} \min =47,363$ meter $=47$ meter

Curve Horisontal (Lokasi Penelitian I)

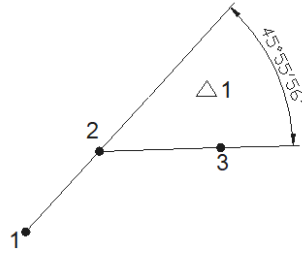




$$
\begin{aligned}
& \Delta_{1} \quad=\mathbf{4 5}^{0}{ }^{\prime} 5^{\prime} 56^{\prime \prime} \\
& \text { Maka : } \mathrm{LC}_{\text {analisa }} \\
& \mathrm{LC}_{1}=\pi \mathrm{R} \Delta_{1} / 180^{\circ} \\
& =\text { л } \mathrm{x} 47 \mathrm{x} 45^{0} 55^{\prime} 56^{\prime \prime} / 180^{\circ}=37.678 \\
& \text { meter } \\
& \mathrm{C}_{1} \quad=2 \mathrm{R} \sin \left(\Delta_{1} / 2\right) \\
& =2 \times 47 \quad \sin \left(45^{0} 55^{\prime} 56^{\prime \prime} / 2\right)=36.678 \\
& =47 x \tan \left(45^{\circ} 55^{\prime} 56^{\prime \prime} / 2\right) \\
& =19.918 \text { meter } \\
& \mathrm{ES}_{1}=\mathrm{T} \tan \left(\Delta_{1} / 4\right) \\
& =33.866 \tan \left(45^{\circ} 55^{\prime} 56^{\prime} / 4\right)=4.046
\end{aligned}
$$

meter.

Hasil penelitian Kurve Horisontal : Data panjang (lengkungan dilapangan) $\mathrm{LC}_{\text {lapangan }}=$ 52 meter, dan $L_{\text {analisa }}=37.678$ meter

\section{Curve Horisontal (Lokasi Penelitian II)}

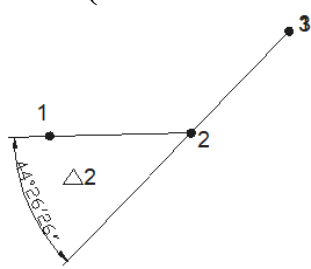

$$
\begin{array}{ll}
\Delta_{2} & =\mathbf{4 4}^{\mathbf{0}} \mathbf{2 6} \mathbf{\prime 2 6}^{\prime \prime} \\
\text { Maka }: & \mathrm{LC} \text { analisa } \\
\mathrm{LC}_{2} & =л \mathrm{R} \Delta_{2} / 180^{0} \ldots \ldots \ldots \ldots \ldots .(10) \\
& =\pi \mathrm{x} 47 \mathrm{x} 44^{0} 26^{\prime} 26^{\prime \prime} / 180^{\circ}=36.455 \\
\text { meter } & \\
\mathrm{C}_{2} & =2 \mathrm{R} \sin \left(\Delta_{2} / 2\right) \ldots \ldots \ldots \ldots .(11) \\
& =2 \mathrm{x} 47 \quad \sin \left(44^{0} 26^{\prime} 26^{\prime \prime} / 2\right)=35.548
\end{array}
$$

meter

$$
\begin{aligned}
\mathrm{T}_{2} & =\mathrm{R} \tan \left(\Delta_{2} / 2\right) \ldots \ldots \ldots \ldots \ldots(12) \\
& =47 \mathrm{xtan}\left(44^{0} 26^{\prime} 26^{\prime \prime} / 2\right) \\
& =19.199 \text { meter } \\
\mathrm{ES}_{2} & =\mathrm{T} \tan \left(\Delta_{2} / 4\right) \ldots \ldots \ldots \ldots \ldots \ldots(13) \\
& =16.340 \tan \left(44^{0} 266^{\prime} 26 " / 4\right)=3.770 \mathrm{~m} .
\end{aligned}
$$

Hasil penelitian Kurve Horisontal : Data panjang (lengkungan dilapangan) $\mathrm{LC}_{\text {lapangan }}=$ 63 meter, dan $\mathrm{LC}_{\text {analisa }}=36.455$ meter

\section{Curve Horisontal (Lokasi Penelitian III)}

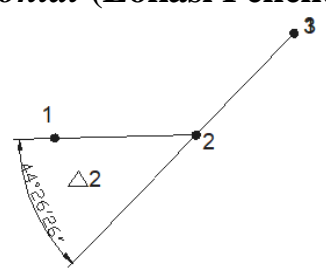

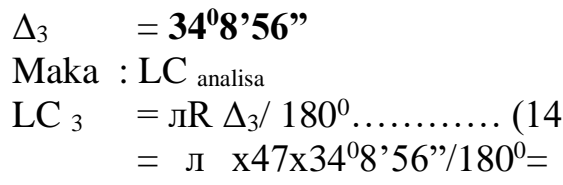

28.012

meter

$\mathrm{C}_{3} \quad=2 \mathrm{R} \sin \left(\Delta_{3} / 2\right)$.

$$
\begin{aligned}
& =2 \mathrm{x} 47 \sin \left(34^{0} 8^{\prime} 56^{\prime \prime} / 2\right)=27.599 \text { meter } \\
\mathrm{T}_{3} & =\mathrm{R} \tan \left(\Delta_{3} / 2\right) \ldots \ldots \ldots \ldots \ldots . .(16) \\
& =47 \mathrm{xtan}\left(34^{0} 8^{\prime}, 56^{\prime \prime} / 2\right) \\
& =14.436 \text { meter } \\
\mathrm{ES}_{3} & =\mathrm{T} \tan \left(\Delta_{3} / 4\right) \ldots \ldots \ldots \ldots \ldots(17) \\
& =12.286 \tan \left(34^{\circ} 8,56 " / 4\right)=2.167 \mathrm{~m} .
\end{aligned}
$$

Hasil penelitian Kurve Horisontal : Data panjang (lengkungan dilapangan) $\mathrm{LC}_{\text {lapangan }}=$ 54 meter, dan $\mathrm{LC}_{\text {analisa }}=28.012$ meter Curve Horisontal (Lokasi Penelitian IV)

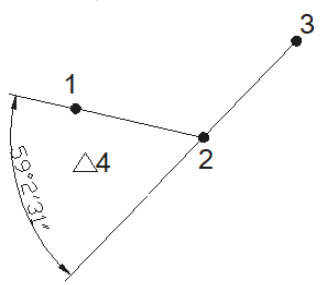

$$
\begin{aligned}
& \Delta_{3}=59^{0} 2^{\prime} 31^{\prime \prime} \\
& \text { Maka : } \mathrm{LC}_{\text {analisa }} \\
& \mathrm{LC}_{3}=\pi \mathrm{R} \Delta_{3} / 180^{\circ} \ldots \ldots \ldots .(18) \\
& =\text { л } \times 47 \times 59^{0} 2^{\prime} 31^{\prime \prime} / 180^{0}= \\
& \text { meter } \\
& \mathrm{C}_{3} \quad=2 \mathrm{R} \sin \left(\Delta_{3} / 2\right) \ldots \ldots \ldots . .(19) \\
& =2 \times 47 \sin \left(59^{\circ} 2^{\prime} 31^{\prime \prime} / 2\right)=46.318 \text { meter } \\
& \mathrm{T}_{3}=\mathrm{R} \tan \left(\Delta_{3} / 2\right) \ldots \ldots \ldots \ldots(20) \\
& =47 x \tan \left(59^{0} 2{ }^{\prime} 31^{\prime \prime} / 2\right) \\
& =26.614 \text { meter } \\
& \mathrm{ES}_{3} \quad=\mathrm{T} \tan \left(\Delta_{3} / 4\right) \ldots \ldots \ldots .(21) \\
& =12.286 \tan \left(59^{\circ} 2^{\prime} 31^{\prime \prime} / 4\right)=7.012 \mathrm{~m} \text {. }
\end{aligned}
$$

Hasil penelitian Kurve Horisontal : Data panjang (lengkungan dilapangan) $\mathrm{LC}_{\text {lapangan }}=$ 49 meter, dan $\mathrm{LC}_{\text {analisa }}=48.432$ meter

\section{Perhitungan Geometrik \\ (Curve Vertikal)}

perhitungan kurve vertikal dari ke empat lokasi penelitian sebagai berikut:

Kurve Horisontal (Lokasi Penelitian I)
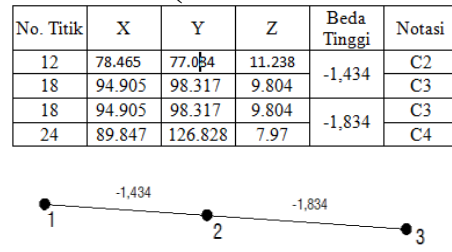

Beda Tinggi Lokasi Penelitian I

$$
\begin{aligned}
& \begin{array}{l}
\operatorname{g1}(\%)= \\
\frac{\text { Elv.PVI-Elv.PLV }}{\frac{1}{2} L V} \times 100 \%
\end{array} \\
& \frac{\mathrm{g} 2(\%)}{\frac{\mathbf{E l v . P T V}-\text { Elv.PVI }}{2} \boldsymbol{L V}} \times 100 \%
\end{aligned}
$$$$
=(-1,434 / 23,35) \times 100 \%=
$$$$
-0,0614133 \times 100 \%=
$$$$
-6,14133 \%
$$ 
$=(-1,834 / 28,65) \times 100 \%=$ $-0,0640139 \times 100 \%=$ $-6,40139 \%$

A

$=\mathrm{g} 2-\mathrm{g} 1=-0,0640139-(-$

$0,0614133)$

$=0,0026$

$\mathrm{EV}$

$=\frac{A}{8} \mathrm{LV}=(0,0026 / 8) \times 52$

$=0,0169$ meter

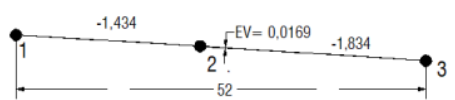

Penentuan EV Lokasi Penelitian I

Hasil penelitian kurve vertikal : dari hasil perhitungan Pergeseran Verikal (EV) sebesar 0,0169 meter

Curve Horisontal (Lokasi Penelitian II)
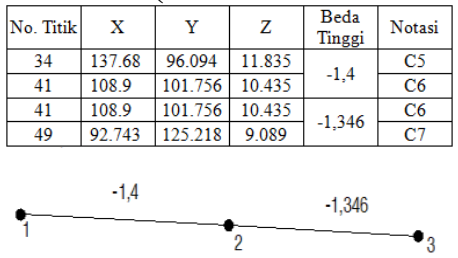

Beda Tinggi Lokasi Penelitian II

$$
\begin{array}{ll}
\mathrm{g} 1(\%) & =\quad \frac{E l v \cdot P V I-E l v . P L V}{\frac{1}{2} L V} \times 100 \% \\
\ldots .(24) & =(-1,4 / 33) \times 100 \%=-0,042424
\end{array}
$$

$\mathrm{X}$

$\mathrm{g} 2(\%)=\quad \frac{\text { Elv.PTV }- \text { Elv.PVI }}{\frac{1}{2} \mathrm{LV}} \times 100 \%$

0,044867

$$
=(-1,346 / 30) \times 100 \%=-
$$

A

$$
\text { x } 100 \%=-4,4867 \%
$$$$
=\mathrm{g} 2-\mathrm{g} 1=-0,044867-(-
$$$$
0,042424)=-0.002443
$$

$\mathrm{EV}$

$$
=\frac{\boldsymbol{A}}{\mathbf{8}} \mathrm{LV}=(-0.002443 / 8) \times 63
$$$$
\text { = - } 0,019249 \text { meter }
$$

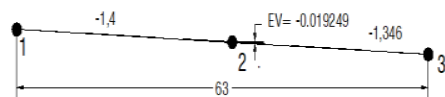

Penentuan EV Lokasi Penelitian II

Hasil penelitian kurve vertikal : dari hasil perhitungan Pergeseran Verikal (EV) sebesar - 0,019249 meter

Kurve Horisontal (Lokasi Penelitian III)

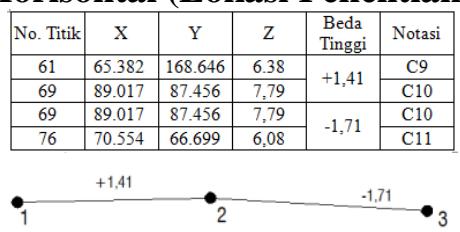

Beda Tinggi Lokasi Penelitian III

$$
\begin{aligned}
& \mathrm{g} 1(\%) \quad=\quad \frac{E l v \cdot P V I-E l v \cdot P L V}{\frac{1}{2} L V} \times 100 \% \\
& =(1,41 / 25,43) \times 100 \%= \\
& \mathrm{x} 100 \%=5,545 \% \\
& \mathrm{~g} 2(\%)= \\
& \frac{\text { Elv.PTV-Elv.PVI }}{\frac{1}{2} L V} \times 100 \\
& -0,1153 \\
& =\frac{A}{8} \mathrm{LV}=(-0,1153 / 8) 54 \\
& =-\mathbf{0 , 7 7 8 3} \text { meter }
\end{aligned}
$$

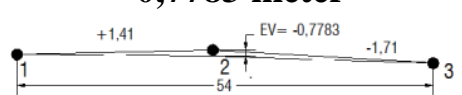

Penentuan EV Lokasi Penelitian III

Hasil penelitian kurve vertikal : dari hasil perhitungan Pergeseran Verikal (EV) sebesar - 0,5515 meter

Curve Horisontal (Lokasi Penelitian IV)

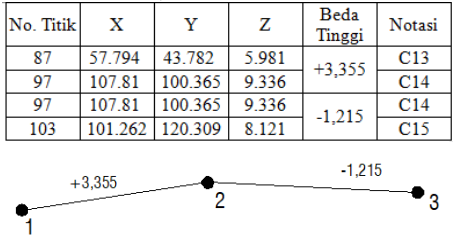

Beda Tinggi Lokasi Penelitian IV

$$
\begin{aligned}
& \mathrm{g} 1(\%) \quad=\frac{\text { Elv.PVI-Elv.PLV }}{\frac{1}{2} \boldsymbol{L V}} \times 100 \\
& =(3,335 / 26) \times 100 \%=0,12827 \\
& = \\
& 12,827 \% \\
& \begin{array}{l}
\mathrm{g} 2(\%)= \\
\frac{\text { Elv.PTV-Elv.PVII}}{\frac{1}{2} L V} \times 100
\end{array} \\
& =(-1,215 / 23) 100=-0,05283 \mathrm{x} \\
& 100 \%=5,283 \% \\
& \text { A } \\
& =\mathrm{g} 2-\mathrm{g} 1=-0,05283-0,12827 \\
& = \\
& \text { - 0,1811 } \\
& =\frac{\boldsymbol{A}}{\mathbf{8}} \mathrm{LV}=(-0,1811 / 8) 49 \\
& =-1,1092 \text { meter }
\end{aligned}
$$

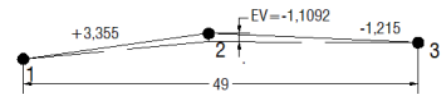

Penentuan EV Lokasi Penelitian IV Hasil penelitian kurve vertikal : dari hasil perhitungan Pergeseran Verikal (EV) sebesar - 1,1092 meter

\section{Perhitungan Perkerasan Lentur}




\section{Metode Bina Marga 2013}

Pada perhitungan perkerasan lentur dengan metode Bina Marga 2013, adapun langkahlangkahnya sebagai berikut :

a. Penetapan Umur Rencana (UR) $=20$ Tahun (direncanakan), sesuai Manual Perkerasan jalan No.02/M/BM/2013 halaman 9, yaitu lapisan lentur berbutir dan CTB

b. Klasifikasi Kendaraan dan Nilai VDF standar

\begin{tabular}{|l|r|}
\hline \multicolumn{1}{|c|}{ Jenis Kendaraan } & VDF4 \\
\hline $\begin{array}{l}\text { Kendaraan ringan, mobil } \\
\text { pribadi, pick up, mobil box, } \\
\text { mobil hantaran. }\end{array}$ & 0,3 \\
\hline Bus & 1,0 \\
\hline Truk 2 as & 0,8 \\
\hline Truk 3 as & 7,6 \\
\hline Truk Gandengan, semi/trailer & 13,6 \\
\hline
\end{tabular}

c. Menghitung ESA 20, dengan pertumbuhan lalu lintas (i) $=5 \%$ (untuk jalan Arteri dan perkotaan).

d. Menghitung faktor pengali pertumbuhan lalu lintas (R)

i $=0,05(5 \%)$

$\mathrm{UR}=20$ Tahun

$\mathrm{R}=(1+0.01 \mathrm{i})^{\mathrm{UR}}-1 /(0.01 \mathrm{i})$

$R=(1+0,01 * 0,05)^{\wedge} 20-1$

$R=20,09528561$

e. Nilai Traffic Multiplier $(\mathrm{TM})=1,8-2,0$, disini diambil rata-rata yaitu 1,9

f. Menentukan Faktor Distribusi Lajur (DL) = $80 \%$ dengan 2 lajur setiap arah

g. Perhitungan CESA4, CESA5 dan ESA 20 tahun

\begin{tabular}{|c|c|c|c|c|c|c|}
\hline No & Jenis Kendaran & \begin{tabular}{|c|} 
UHR 2019 \\
Kendran//am
\end{tabular} & VDF4 & $\begin{array}{c}\text { BSA4 } \\
\text { VDE4"Jumlah per hari }\end{array}$ & $\begin{array}{c}\text { CESA4 } \\
\text { ESA4" } R^{*} 365^{*} \mathrm{DL}\end{array}$ & $\begin{array}{c}\text { ESA5 } \\
\text { CESA4 TM }\end{array}$ \\
\hline \multirow[t]{2}{*}{2} & \multirow{2}{*}{ 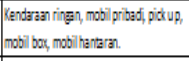 } & 1385. & 0.3 & 41:562 & 304525.5624 & 57921986606 \\
\hline & & & & & & \\
\hline 3 & 3.5 & 446: & 0.7 & 31.2373 & 183266.1334 & 34862626394 \\
\hline 4 & Trek 2 2as & 7729 & 0.8 & 61.83333333 & 362827.0001 & 6993714522 \\
\hline 5 & Truk $3 a s$ & (5.22. & 1.6 & 7233333333 & 42439.256 & 806445260 \\
\hline 6 & Truk Gendegan, seni|yzaler & 1022 & 13.6 & 1399666660 & 821299.685 & 1560659.395 \\
\hline \multicolumn{4}{|l|}{ Jumlah } & 346.93333333 & 2095714.683 & $3,983,757,90$ \\
\hline
\end{tabular}

h. Pemilihan jenis perkerasaan pada ESA 20 tahun $=3.983 .757,90$.

i. Solusi desain pondasi jalan minimum. CBR Tanah Dasar $(\geq 6 \%)$, Tebal minimum peningkatan tanah dasar (Tidak Perlu Peningkatan).

j. Desain perkerasan lentur opsi biaya minimumpada ESA 20 tahun = 3.983.757,90 HRS WC, HRS BASE, LPA kelas A, LPA kelas B.

k. Tebal lapis perkerasan

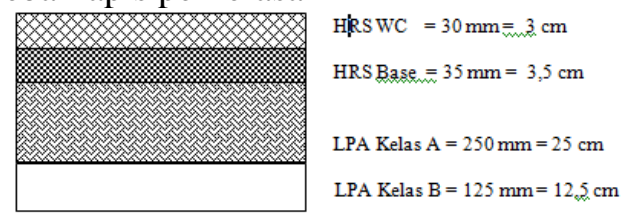

Gambar 6.Struktur Perkerasan Jalan Raya

\section{Inventarisasi Jalan}

Marka Jalan

Menurut Peraturan Menteri Perhubungan Republik Indonesia Nomor PM 34 Tahun 2014 Tentang Marka Jalan pasal 17 ayat (1) sampai ayat (3) sudah dijelaskan tentang fungsi, jenis, dan ukuran marka. Pada pasal 60 ayat (1) dijelaskan tentang penempatan marka membujur berupa garis utuh.

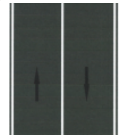

Bentuk dan warna marka membujur dilapangan

Dimensi marka dilapangan dengan peraturan diatas telah sesuai yaitu $12 \mathrm{~cm}$, dan berupa marka membujur garis utuh jadi tidak perlu adanya perbaikan marka.

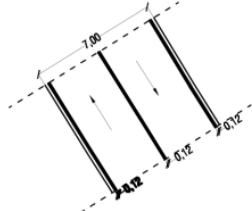

\section{Lampu Penerangan Jalan}

Menurut Peraturan Menteri Perhubungan Republik Indonesia Nomor PM 27 Tahun 2018 Tentang Alat Penerangan Jalan pasal 46 huruf (a) jalan arteri, ketinggian tiang paling rendah 9.000 (sembilan ribu) milimeter. Pada pasal 101 penempatan dan pemasangan alat penerangan jalan sebagaimana dimaksud dalam Pasal 99 disebelah kiri dan/ atau kanan jalan menurut arah lalu lintas pada jarak paling sedikit 600 (enam ratus) milimeter diukur dari bagian terluar bangunan konstruksi alat penerangan jalan ke tepi paling kiri dan/ atau kanan jalur ruang lalu lintas atau kerb.

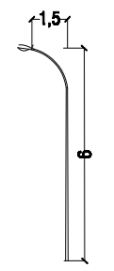

Detail Lampu Penerangan Umum

\section{Rambu-rambu Lalu Lintas}

Menurut Peraturan Menteri Perhubungan Republik Indonesia Nomor PM 13 Tahun 2014 Tentang Rambu Lalu Lintas pasal 7 ayat (1) menjelaskan fungsi rambu peringatan. Pada pasal 8 disebutkan macam-macam rambu peringatan, sedangkan pasal 35 menjelaskan ketentuan letak rambu dan pasal 36 menerangkan ketentuan tinggi rambu. Pada pasal 37 menyatakan ketentuan kecepatan 
rencana sesuai dimensi rambu, sedangkan pasal 39 menjelaskan tentang jarak rambu dengan titik awal tikungan.

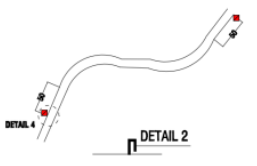

Detail Perencanaan Rambu

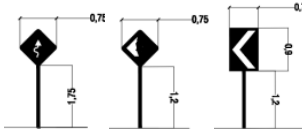

Detail Rambu Tanda Berbelok \& Rambu Peringatan

\section{KESIMPULAN DAN SARAN}

Penelitian ini menghasilkan beberapa kesimpulan dan saran yaitu sebagai berikut.

\section{Kesimpulan}

Penelitian ini menghasilkan kesimpulan sebagai berikut.

1. hasil DS $2019=0.185$ (A) adalah dalam zona harus stabil. Pengemudi memiliki kebebasan yang cukup untuk memilih kecepatannya Dan untuk DS $2039=0.492$ (C)

2. Perencanaan tebal perkerasan lentur menggunakan metode Bina Marga 2013 dengan $\mathrm{i}=5 \%$ dan umur rencana $(\mathrm{UR})=$ 20 tahun pada Jalan raya Banyuwangi Kab. Jember didapat hasil Metode Bina Marga 2013 : tebal $44 \mathrm{~cm}$ yang dimana HRS WC $=3 \mathrm{~cm}$, HRS Base $=3.5 \mathrm{~cm}$, LPA Kelas A $=25 \mathrm{~cm}$, LPA Kelas B $=12,5$ $\mathrm{cm}$.

3. Pada perhitungan ke empat lengkungan horizontal terdapat perbedaan panjang lengkungan lapangan (LC lapangan) dengan lengkungan analisa ( $\mathrm{LC}$ analisa). Adapun perbedaan panjang sebagai berikut : Lokasi penelitian I : $\mathrm{LC}_{\text {lapangan }}=52$ meter, $\mathrm{LC}$ analisa $=37,678$ meter, Lokasi penelitian II : LC lapangan $=63$ meter, $\mathrm{LC}_{\text {analisa }}=36,455$ meter, Lokasi penelitian III: $\mathrm{LC}_{\text {lapangan }}=54$ meter, $\mathrm{LC}_{\text {analisa }}=28,120$ meter, Lokasi penelitian IV : $\mathrm{LC}$ lapangan $=49$ meter, $\mathrm{LC}$ analisa $=$ 48,432 meter. Dikarenakan dari lokasi penelitian I-IV LC lapangan lebih panjang dari $\mathrm{LC}_{\text {analisa }}$ maka tidak perlu adanya perbaikan rute horisontalnya. Pada perhitungan ke empat lengkungan vertikal didapatkan, perhitungan ke I kurve vertikal didapat EV sebesar 0,0169, perhitungan ke II kurve vertikal didapat EV sebesar - 0,019249, perhitungan ke III kurve vertikal didapat
EV sebesar $-0,7783$ meter, perhitungan ke IV kurve vertikal didapat EV sebesar 1,1092. Dalam analisa alinyemen vertikal terdapat timbunan dan galian sebesar angka yang didapat dari perhitungan disetiap lokasi penelitian.

4. Hasil pengambilan data dan perencanaan kelengkapan inventaris jalan pada lokasi penelitian didapatkan hasil Tiang Listrik = 8 titik, Lampu penerangan jalan $=10$ titik, Rambu-rambu lalu lintas tidak ada, marka = marka membujur berupa garis utuh. Setelah direncanakan penambahan titik didapatkan hasil Tiang listrik $=8$ titik, Lampu penerangan jalan $=10$ titik, Rambu - rambu lalu lintas = penambahan 8 titik, dan marka jalan $=$ marka membujur berupa garis utuh.

\section{Saran}

Penelitian ini menghasilkan saran sebagai berikut.

1. Perlunya pemeliharaan dan pengawasan jalan raya Gumitir Kabupaten Jember KM. 229+644 KM.230+019.., terutama kendaraan yang melintas pada beban kendaraan dan angkutannya.

2. Perlunya ada penimbunan dan galian pada titik dilokasi yang menurut perhitungan kurve vertikal tersebut di atas pada jalan Raya Gumitir STA. $229+644-230+019$.

3. Untuk pembangunan atau peningkatan jalan, diperlukan evaluasi ulang untuk tebal perkerasannya dengan metode Bina Marga 2103 pada jalan Raya Gumitir STA 229+644 - 230+019.

4. Untuk kelengkapan inventaris jalan, diperlukan evaluasi ulang oleh pihak terkait agar tercapainya kenyamanan dan keselamatan bagi pengguna jalan pada jalan Raya Gumitir STA 229+644 - 230+019.

5. Perlunya Pos-pos pantau (Polri/Dishub) pada raya Gumitir terutama STA 229+644-230+019.

\section{DAFTAR PUSTAKA}

Alamsyah, Alik Ansyori, Ir, MT., 2001. Rekayasa Jalan Raya, Universitas Muhammadiyah Malang Press, Malang. 
Departemen Bina Marga, 1987 dan Bina Marga, 2013, Perencanaan Tebal Perkerasan, Jakarta.

Direktorat Jenderal Bina Marga Dep. PU dan TL., 1997. Tata Cara Perencanaan Geometrik Jalan Antar Kota, Jalan No. 038/TBM/1997, Jakarta.

Direktorat Jenderal Bina Marga Dep. PU dan TL., 1976. Peraturan Perencanaan Geometrik Jalan Raya No. 13/1970, Badan Penerbit PU, Jakarta.

Galih Alif Maulana, 2018, Perencanaan Tebal Perkerasan dan Geometrik JLS Jember, Tugas Akhir, Unmuh Jember

MKJI, 1997, Jakarta

Menteri Perhubungan R.I., 2014. Peraturan Menteri Perhubungan Republik Indonesia No. PM 13 tahun 2014 Tentang Rambu Lalu Lintas, Badan Penerbit Menteri Perhubungan, Jakarta

Menteri Perhubungan R.I., 2014. Peraturan Menteri Perhubungan Republik Indonesia No. PM 34 tahun 2014 Tentang Marka Jalan, Badan Penerbit Mentri Perhubungan, Jakarta.
Menteri Perhubungan R.I., 2018. Peraturan Menteri Perhubungan Republik Indonesia No. PM 27 tahun 2018 Tentang Alat Penerangan Jalan, Badan Penerbit Menteri Perhubungan, Jakarta.

Fajar Dwi Mulyono, 2018. Evaluasi Geometrik-Kinerja dan Perkerasan Pada Jalan Raya Baluran (Studi Kasus Jalan Raya Bajulmati Wongsorejo), Tugas Akhir, Unmuh Jember.

S. Hendratingsih.S, 1986, Stake Out Jalan, ITB. Bandung.

Taufan Abadi, 2016. Route Surveying dan Masterplan, Unmuh Jember.

Tumewu, Lien, 1987. Rote Survey, ITB, Bandung. 